\title{
Pengembangan Pendidikan Formal: Studi Kebijakan Kepemimpinan Kiai di Pondok Pesantren Tarbiyatul Ummah Muaro Jambi
}

\author{
A. Khalik ${ }^{1 *}$, Bawaihi ${ }^{2}$, \& Ayu Yulianti ${ }^{3}$ \\ Universitas Islam Negeri Sulthan Thaha Saifuddin, Jambi \\ *corresponding author: abdulkhalik@uinjambi.ac.id
}

\begin{abstract}
:
This research is based on a strong tendency in pesantren to consolidate institutional organizations, particularly on aspects of leadership and management. This research uses descriptive qualitative methods by reviewing the kiai leadership policy in the development offormal education at SMP IT Pondok Pesantren Tarbiyatul Ummah Muaro Jambi. The results showed that kiai policy in the development of formal education was carried out by adjusting the conditions of boarding schools and considering various ideas / suggestions to be mutually agreed upon. While in formulating its policy, kiai involves all administrators of educational institutions and gives authority to implement policies that have been decided. The implementation of the policy is socialized through meetings with institutions to strengthen the flow of information on the policies to be implemented.
\end{abstract}

KEYWORDS: Policy; kiai leadership; development of formal education.

\begin{abstract}
ABSTRAK:
Penelitian ini didasarkan oleh kecenderungan yang kuat di pesantren untuk melakukan konsolidasi organisasi kelembagaan, khususnya pada aspek kepemimpinan dan manajemen. Penelitian ini menggunakan metode kualitatif deskriptif dengan mengkaji tentang kebijakan kepemimpinan kiai dalam pengembangan pendidikan formal di SMP IT Pondok Pesantren Tarbiyatul Ummah Muaro Jambi. Hasil penelitian menunjukkan kebijakan kiai dalam pengembangan pendidikan formal dilakukan dengan menyesuaikan kondisi pondok pesantren serta mempertimbangkan berbagai ide/saran untuk disepakati bersama. Sedangkan dalam merumuskan kebijakannya, kiai melibatkan seluruh pengurus lembaga pendidikan dan memberi wewenang untuk melaksanakan kebijakan yang telah diputuskan. Pelaksanaan kebijakan tersebut disosialisasikan melalui rapat dengan lembaga guna memantapkan alur informasi atas kebijakan yang akan dilaksanakan.
\end{abstract}

KATA KUNCI: Kebijakan; kepemimpinan kiai; pengembangan pendidikan formal.

Copyright @ Published by Program Studi Manajemen Pendidikan Islam Fakultas Tarbiyah dan Keguruan

Universitas Islam Negeri Sulthan Thaha Saifuddin jambi

Mendalo Darat, Muaro Jambi, 36361, Indonesia 


\section{PENDAHULUAN}

Pendidikan pada hakikatnya merupakan usaha sadar untuk mengembangkan kepribadian yang berlangsung seumur hidup baik di sekolah maupun madrasah. Dalam konteks Islam, pendidikan bermakna bimbingan terhadap pertumbuhan rohani dan jasmani menurut ajaran Islam dan hikmah mengarahkan, mengajarkan, melatih, mengasuh dan mengawasi berlakunya semua ajaran Islam (Tohirin, 2007: 5). Program pembaruan dalam bidang pendidikan nasional merupakan salah satu upaya untuk menyiapkan masyarakat dan bangsa Indonesia yang mampu mengembangkan kehidupan demokratis yang mantap dalam memasuki era globalisasi dan reformasi sekarang ini (Rusman, 2009: 1). Pengembangan pendidikan, salah satunya melalui sekolah terpadu ke arah pemaduan sistem sekolah dan pesantren brtujuan untuk mencapai keunggulan, baik pada aspek akademik, non akademik, maupun karakter kepribadian yang kuat, kokoh dan mantap dalam diri peserta didik, merupakan salah satu jawaban alternatif dalam menghadapi era globalisasi (Muhaimin, 2009: 103).

Pembelajaran terpadu di SMP IT Pondok Pesantren Tarbiyatul Ummah merupakan suatu pendekatan dalam pembelajaran yang secara sengaja mengaitkan beberapa aspek baik dalam intra mata pelajaran maupun antar mata pelajaran. Pemaduan tersebut mengarahkan siswa untuk memperoleh pengetahuan dan keterampilan secara utuh sehingga pembelajaran menjadi bermakna bagi siswa. Undang-Undang Sistem Pendidikan Nasional (UU Sisdiknas) No. 20 Tahun 2003 menjelaskan bahwa sistem pendidikan dibagi ke dalam jalur, jenjang, dan jenis pendidikan. Jalur pendidikan meliputi pendidikan formal, non formal dan informal. Jenjang pendidikan meliputi pendidikan dasar, pendidikan menengah dan pendidikan tinggi. Sedangkan jenis pendidikan meliputi pendidikan umum, kejuruan, akademik, profesi, keagamaan dan pendidikan khusus. Jalur pendidikan formal dibagi dalam jenjang pendidikan dasar, pendidikan menengah dan pendidikan tinggi dengan menggunakan kurikulum yang telah ditetapkan pemerintah. Namun sistem pendidikan tersebut belum dapat mencapai tujuan pendidikan nasional. Pasalnya pendidikan konvensional hanya menekankan pendidikan pada akademik siswanya, dan pendidikan serta materi keagamaan hanya diberikan sebagai materi pelengkap dan materi tambahan, sementara pendidikan agama 
tersebut banyak memberikan pengaruh pada budi pekerti dan pendidikan akhlaq siswa (Hidayat, 2009).

Dewasa ini telah tercatat kurang lebih 39.449 pondok pesantren/madrasah yang telah berperan secara aktif dalam mencerdaskan masyarakat dan membina lingkungan, sehingga pesantren telah berperan pula sebagai alat transformasi kultural dalam kehidupan masyarakat (Munif, 1992). Pesantren yaitu suatu tempat pendidikan dan pengajaran yang menekankan pelajaran agama Islam dengan didukung asrama sebagai tempat tinggal santri yang permanen (Qomar, 2007). Pondok pesantren sebagai lembaga pendidikan dan lembaga sosial kemasyarakatan telah memberikan warna dan corak khas dalam masyarakat Indonesia. Pondok pesantren tumbuh dan berkembang bersama masyarakat sejak berabad-abad, oleh karena itu secara kultural lembaga ini telah ikut serta memberikan corak kehidupan kepada masyarakat yang senantiasa tumbuh dan berkembang (Munif, 1992).

Sebagai salah satu unsur dominan dalam kehidupan sebuah pesantren, kiai mengatur irama perkembangan dan kelangsungan kehidupan pesantren dengan keahlian, kedalaman ilmu, karismatik dan keterampilannya (Hasbullah, 1996). Segala bentuk kebijakan penyelenggaraan pendidikan, baik menyangkut format kelembagaan berikut penjenjangannya, kurikulum yang dipakai acuan, metode pengajaran dan pendidikan yang diterapkannya, keterlibatan dalam aktivitas di luar maupun sistem pendidikan yang diikuti adalah wewenang mutlak kiai (Muzammil, 2004).

Dengan demikian secara otomatis tugas dan tanggung jawab kiai sebagai pimpinan pesantren semakin berat dan komplek serta tidak mungkin dapat diemban oleh kiai sendiri. Menyadari hal ini, Pondok Pesantren Tarbiyatul Ummah selanjutnya mengembangkan pola kelembagaan yayasan, sehingga segala urusan pondok pesantren serta penyelenggaraan pendidikan formal baik urusan internal atau eksternal ditangani oleh kepemimpinan yayasan sesuai dengan fungsi dan peran masing-masing komponen yayasan.

Posisi kiai sendiri dalam yayasan tersebut adalah sebagai dewan pembina dan pengasuh, merupakan posisi tertinggi dalam penentuan dan pengambilan kebijakan yayasan pondok pesantren, baik dalam kebijakan edukatif maupun kebijakan non edukatif. Dalam proses pengambilan kebijakan pesantren, kiai menduduki posisi penentu kebijakan, khususnya 
dalam kebijakan pengembangan pendidikan formal. Kebijakan tersebut juga senantiasa melibatkan dewan-dewan yang ada. Hal ini dilakukan agar kebijakan yang diambil benar-benar berkualitas. Di sisi lain, keterlibatan stakeholder yayasan dalam pengambilan kebijakan menjadikan masyarakat merasa memiliki dan ikut bertanggung jawab terhadap implementasinya.

Adapun pengembangan sekolah merupakan proses pengembangan sebuah rencana untuk meningkatkan kinerja sebuah sekolah secara berkesinambungan. Munculnya kepemimpinan yayasan pesantren ini juga menimbulkan beberapa persoalan , diantaranya adalah apakah kepemimpinan yayasan telah benar-benar demokratis dan terbuka; apakah dalam proses pengambilan kebijakan, kepemimpinan di SMP IT Pondok Pesantren Tarbiyatul Ummah Muaro Jambi sudah melibatkan seluruh komponen Yayasan; atau apakah dalam mengimplementasikan kebijakannya, kepemimpinan pesantren sudah mempersiapkan perangkat implementasi kebijakan dengan baik. Pertanyaan-pertanyaan tersebut muncul berjalan seiring dengan perkembangan zaman.

Dalam kasus pengambilan kebijakan pengembangan pendidikan di SMP IT Pondok Pesantren Tarbiyatul Ummah yang dalam hal ini dilaksanakan oleh kepemimpinan pesantren sangat menarik untuk dikaji dan diteliti dan juga dari segi tahapanya. Kepemimpinan selanjutnya berpola pada kepemimpinan kolektif. Selain itu, merupakan Pondok Pesantren Tarbiyatul Ummah pondok salafi yang tidak menutup mata dalam perkembangan pendidikan formal sehingga mentransformasikan diri dalam mengembangkan pendidikan formal di SMP IT Pondok Pesantren Tarbiyatul Ummah Muaro Jambi.

\section{METODE}

Penelitian ini menggunakan metode deskriptif. Pengumpulan data kualitatif dilakukan melalui wawancara mendalam, observasi partisipasi, studi dokumen, dan dengan melakukan triangulasi yang dirancang untuk memperoleh informasi tentang bagaimana Kebijakan Kepemimpinan Kyai dalam Pengembangan Pendidikan Formal di SMP IT Pondok Pesantren Tarbiyatul Ummah Muaro Jambi. Desain penelitian ini menggunakan kualitatif interaktif. Kualitatif interaktif merupakan studi yang mendalam menggunakan 
teknik pengumpulan data langsung dari orang dalam lingkungan alamiahnya dan menginterprestasikan fenomena-fenomena bagaimana orang mencari makna yang terkandung serta membuat suatu gambaran dan menyeluruh dengan deskripsi detail dari informan. Dalam metode kualitatif interaktif peneliti menggunakan studi kasus dalam penelitiannya (Asep Saepul Hamdi dan E. Bahruddin, 2014).

\section{HASIL PENELITIAN DAN PEMBAHASAN}

Kebijakan kiai dalam pengembangan pendidikan formal yang dilakukan di SMP IT Pondok Pesantren Tarbiyatul Ummah Muaro Jambi yaitu dengan menampung aspirasi atau masukan dari kepala lembaga pendidikan formal. Kebijakan kiai dalam pengembangan pesantren dimulai dengan pengamatan lingkungan, masukan dari pimpinan lembaga pondok pesantren Tarbiyatul Ummah sepanjang hal tersebut baik untuk dilaksanakan namun juga melalaui pertimbangan dari dewan pembina pondok pesantren. Berbagai arah usulan kebijakan di pondok pesantren Tarbiyatul Ummah diantaranya terkait skill keterampilan santri, terkait sumber daya manusia pendidik dan tenaga kependidikan, kesiswaan, kurikulum, dan keterbatasan sarana prasarana.

Pendidik dan tenaga kependidikan melalui peningkatan jenjang pendidikan, memberikan sanksi mulai dari teguran, pemanggilan wali santri hingga pengeluaran santri untuk menekan pelanggaran santri terhadap tata tertib. Untuk pembiaasaan dalam hal ibadah adalah dengan pengkondisian santri untuk sholat secara berjamaah di masjid. Untuk mencapai cita-cita tersebut pondok pesantren Tarbiyatul Ummah tidak hanya menyelenggarakan pendidikan formal berbentuk pesantren melainkan juga pendidikan formal mulai dari SMP IT dan SMA IT. Lembaga pendidikan tidak dapat bertahan tanpa adanya kebijakan dalam mengembangkan pendidikannya. Hal ini pula yang dilakukan oleh Pondok Pesantren Tarbiyatul Ummah Muaro Jambi. Dalam proses kebijakan di Pondok Pesantren Tarbiyatul Ummah dimulai dengan melakukan pengamatan lingkungan dan wawasan ke depan pengasuh pesantren.

Perumusan masalah dalam pengambilan kebijakan lebih ditekankan pada pengembangan lembaga yang ada. Hal tersebut dilakukan sesuai tuntutan perkembangan pendidikan sekarang. Pengembangan sekolah dapat 
diwujudkan dari akadmik dan nonakademik. Kiai memiliki beberapa kebijakan meliputi kebijakan dalam bidang sarana prasarana dengan pengadaan gedung baru untuk kegiatan belajar mengajar dan penambahan asrama, Sumber Daya Manusia (SDM), pendidik dan tenaga pendidikan melalui peningkatan jenjang pendidikan, memberikan sanksi mulai dari teguran, pemanggilan wali santri hingga pengeluaran santri untuk menekan pelanggaran santri terhadap tata tertib.

Implementasi kebijakan atau pelaksanaan kebijakan merupakan suatu proses usaha untuk mewujudkan suatu kebijakan yang masih bersifat abstrak ke dalam realita nyata. Pelaksanaan kebijakan merupakan suatu kegiatan untuk menimbulkan hasil (outputs), dampak (out comes), dan manfaat (benefit), serta dampak (impacts) yang dapat dinikmati oleh kelompok sasaran (target groups). Dalam pelaksanaan kebijakan kiai di pondok pesantren Tarbiyatul Ummah dalam pengembangan pendidikan formal melibatkan pengurus lembaga terkait sesuai bidang kebijakan masing-masing.

Adapun upaya yang dilakukan kiai dalam pelaksanaan kebijakan agar menimbulkan efek adalah melalui banyak hal diantaranya dengan memfasilitasi penuh kebutuhan siswa untuk kegiatan intra dan ekstrakurikuler, untuk kebutuhan sarana prasarana berkomunikasi dengan wali santri serta donatur tidak tetap, memfasilitasi penuh untuk kegiatan ekstrakurikuler. Selain itu, upaya yang dilakukan kiai agar kebijakan memperoleh efek di pondok pesantren Tarbiyatul Ummah Muaro Jambi diantaranya menggiatkan peran wali santri agar berpartisipasi aktif dalam pengembangan sarana dan prasarana serta mendukung penuh fasilitas dan SDM guna sukses suatu kebijakan. Evaluasi kebijakan kiai dalam pengembangan pendidikan di SMP IT Pondok Pesantren Tarbiyatul Ummah Muaro Jambi diukur dari semakin banyaknya antusiasme masyarakat yang mempercayakan putra putrinya untuk belajar di pondok pesantren, khususnya di SMP IT.

\section{SIMPULAN}

Pengembangan pendidikan formal di SMP IT Pondok Pesantren Tarbiyatul Ummah, dilakukan melalui penerapan beberapa kebijakan yang meliputi kebijakan dalam bidang sarana prasarana dengan pengadaan gedung 
baru untuk kegiatan belajar mengajar dan penambahan asrama, Sumber Daya Manusia (SDM) pendidik dan tenaga pendidikan melalui peningkatan jenjang pendidikan, memberikan sanksi mulai dari teguran, pemanggilan wali santri hingga pengeluaran santri untuk menekan pelanggaran santri terhadap tata tertib.

Kebijakan kiai dalam pengembangan pendidikan formal yang dilakukan di SMP IT Pondok Pesantren Tarbiyatul Ummah yaitu dengan menampung aspirasi atau masukan dari kepala lembaga pendidikan formal. Kebijakan kiai dalam pengembangan pesantren dimulai dengan pengamatan lingkungan, masukan dari pimpinan lembaga Pondok Pesantren Tarbiyatul Ummah sepanjang hal tersebut baik untuk dilaksanakan namun juga melalui pertimbangan dari dewan pembina pondok pesantren. Berbagai arah usulan kebijakan di pondok pesantren Tarbiyatul Ummah diantaranya terkait skill keterampilan santri, terkait sumber daya manusia pendidik dan tenaga kependidikan, kesiswaan, kurikulum, dan keterbatasan sarana prasarana.

\section{REFERENSI}

Kartono, Kartini. (2006). Pemimpin dan Kepemimpinan. Jakarta: Raja Grafindo Persada.

Masyhud, Sulthon dan Khusnurdilo, Moh. (2005). Manajemen Pondok Pesantren. Jakarta: Diva Pustaka.

Qomar, MuZammil. (2204). Pesantren dari Transformasi Metodologi Menuju Demokratis Institusi. Jakarta: Erlangga.

Sagala, Saiful. (2015). "Manajemen dan Kepemimpinan Pendidikan Pondok Pesantren." Jurnal Tarbiyah, 22(2).

Sholichin, Abdul Wahab. (1991). Analisis Kebijakan: dari Formulasi ke Implementasi Kebijakan Negara. Jakarta: Bumi Aksara.

Subarsono. (2015). Analisis Kebijakan Publik Konsep, Teori dan Aplikasi. Yogyakarta: Pustaka Pelajar.

Sugiyono. (2010). Metode Penelitian Pendidikan Pendekatan Kuantitatif, Kualitatif, dan RED. Bandung: Alfabeta.

Suryosubroto, B. (2004). Manajemen Pendidikan di Sekolah. Jakarta: PT. Rineka Cipta.

William, Dunn. (1999). Pengantar Analisi Kebijakan. Yogyakarta: Gadjah Mada University Press. 